\title{
HYPERTROPHIC PULMONARY OSTEOARTHROPATHY
}

\author{
Jean Ginsburg, M.A., D.M.(Oxon.) \\ From the Department of Obstetrics and Gyncecology, Charing Cross Hospital Medical School, \\ London, W.C.2
}

THE syndrome of hypertrophic pulmonary osteoarthropathy is one of the most striking systemic manifestations of a localized carcinoma. The majority of cases are associated with a primary carcinoma of the bronchus, of any cell type, but which is frequently peripheral in position (Ray and Fisher, 1953; Semple and McCluskie, 1955). Pulmonary osteoarthropathy may also be secondary to pleural tumours (Price Thomas and Drew, 1953; Shapiro, 1956), mediastinal carcinomata and pulmonary Hodgkin's disease (Mendlowitz, 1942), but is rarely found with secondary deposits in the lungs.

Signs and symptoms are generally maximal in the periphery of the limbs, the classical case being characterized by marked clubbing of the fingers and toes, hot painful swelling of large joints such as the knees, ankles or wrists, and by thickening of the skin over affected bones. In some patients, marked pitting odema of the legs may extend from the feet to the knees. Pain in the jaw or clavicle may also indicate involvement of bones other than those of the limbs. On radiological examination of affected limbs, a characteristic periostitis is apparent in the shafts of the long bones. In the early case, a thin, irregular radio-opaque line of new bone at the distal end of the diaphysis is separated from the underlying denser cortex by a narrow radio-translucent band; in advanced cases, the periostitis increases in extent and may eventually fuse with the cortex of the shaft. The new bone formation is always, however, confined to the diaphysis and never involves the joint itself. The name given to the syndrome by Pierre Marie (1890) is indeed misleading; though effusions and pain in the joints may be the presenting clinical features, the diagnostic radiological and pathological changes are confined to the diaphyses. The bones of the lower leg and forearm are first affected. Later, periostitis may be found in other long bones, in the small bones of the hands and feet and, in advanced cases, especially in animals, the jaw, ribs, clavicle, pelvic girdle and even the vertebræ may be affected.

A paper read to the Harveian Society of London on April 17, 1963.

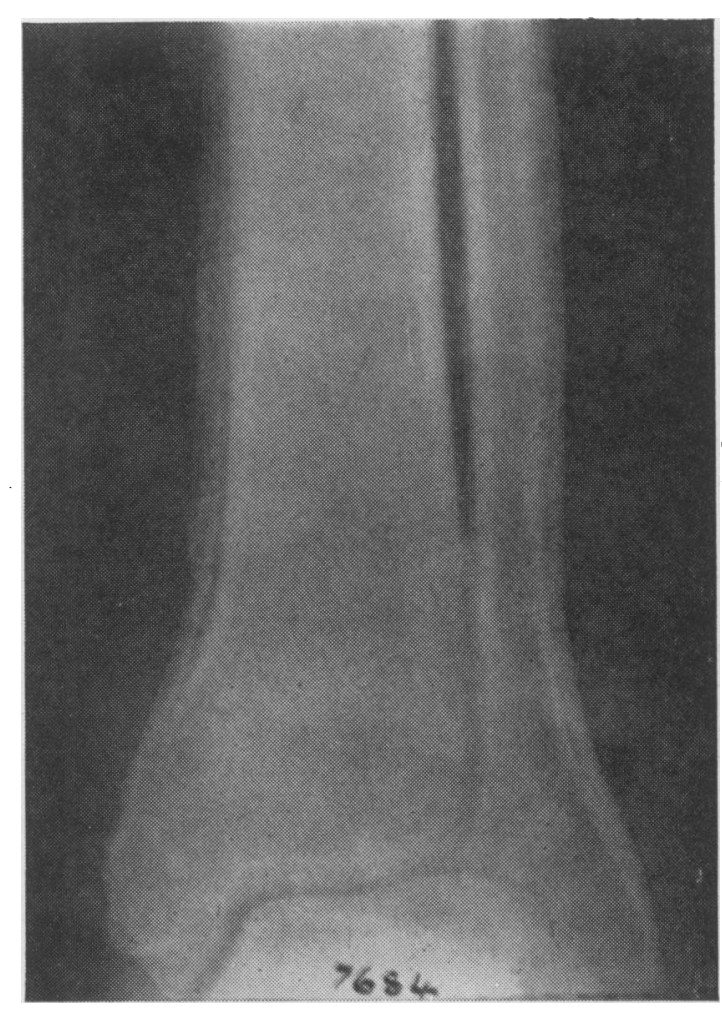

FIG. I.-Antero-posterior radiograph of lower end of tibia and fibula from patient with osteoarthropathy. (By courtesy of Dr. M. E. Turner-Warwick.)

It must be emphasized that the diagnostic feature of this condition is the radiological change in bone. The simultaneous occurrence of finger clubbing and 'arthralgia' does not suffice for a diagnosis of osteoarthropathy; unequivocal radiological evidence of periostitis in the shafts of limb bones must also be present.

Joint pain and swelling are relieved immediately after surgical removal of the pulmonary cause, but the new-formed bone is only gradually resorbed. Relief of joint symptoms has been noted after radiotherapy to inoperable bronchial carcinomata and after cortisone (de Sèze, Hubault and Debeyre, 1952; Shapiro, 1956; Coury, 1960), but 
without subsequent regression of the periostitis. Alleviation of pain and swelling have also been reported after ligation of the pulmonary artery (Wyburn-Mason, 1948) and after vagotomy (Hansen, 1952; Flavell, 1956). Similarly, in these cases, radiological regression of the periostitis was not apparent: indeed, in one patient, additional layers of periosteal new bone were deposited after vagotomy, during a period of symptomatic improvement (Diner, 1962).

\section{Histology of the Periostitis}

Layers of thin cancellous bone are deposited irregularly on the outside of the cortex, especially on the lateral aspects of the shafts (Parkes-Weber, 1909; Crump, 1929; Compère, Adams and Compère, 1935; Gall, Bennett and Bauer, 195I). The new bone is friable and vascular, the periosteum is thickened and there is marked cellular infiltration into the surrounding connective tissue (Gall, Bennett and Bauer, 195I; Ginsburg, 1958; Coury, 1960). In cases of long standing, osteoid tissue is deposited in the inner layers, so that the thickened periosteum is separated from compact bone of the old cortex (Gall and others, I95I).

\section{Other Causes of Osteoarthropathy}

Similar clinical and radiological changes in the limbs have also been recorded in non-malignant pulmonary disease such as hydatid cyst (Thiodet, Fourrier, Chevro : and Massonat, 1950) and bronchiectasis (Mendlowitz, 1942; Ginsburg, 1958), and also in association with hepatic disease, especially biliary cirrhosis (Gilbert and Fournier, 1895; Parmentier and Castaigne, I905; Meyer and Sarasin, 1950) in the apparent absence of primary pulmonary disease.

The precise incidence of the syndrome in bronchial carcinoma has not been determined. In two small series confined to patients undergoing resection, the incidence varied between 5 and $10 \%$ (Ray and Fisher, 1953; Wierman, Claggett and McDonald, 1954), but in larger, unselected series, the incidence was only $2 \%$ (Semple and McCluskie, 1955; Ginsburg, 1959). There is no reliable information on the incidence of osteoarthropathy in other conditions.

\section{Differential Diagnosis}

The combination of marked clubbing of the fingers, swollen painful joints and periostitis, secondary to pulmonary disease, must be differentiated from two other uncommon syndromes.

\section{Pachydermoperiostosis}

This descriptive term has been applied to patients with marked clubbing, enlargement and profuse sweating of the extremities, thickening of the skin, especially over the face so that the features coarsen, and with periostitis in the long bones, but with no evidence in life of intrathoracic disease (Touraine, Solénte and Golé, 1935; Camp and Scanlan, 1948; Angel, 1957; Vogl and Goldfischer, 1962). Though the radiological and histological changes in the bones of the limbs are similar to those seen in advanced cases of pulmonary arthropathy, the joints are not hot or tender. The condition is familial in at least $30 \%$ of cases and, on the whole, patients with pachydermoperiostosis have a similar facial appearance. The syndrome has been considered as a variant of pulmonary arthropathy and labelled 'idiopathic osteoarthropathy', but in the absence of adequate post-mortem studies, the precise relationship between pachydermoperiostosis (or 'idiopathic osteo arthropathy') and hypertrophic pulmonary osteo-z arthropathy secondary to pulmonary disease is unknown $\mathbb{\Omega}$

\section{Thyroid Acropachy}

This rare syndrome is characterized by clubbing of the fingers and toes, together with periosteal new bone formation maximal in the phalanges and metacarpals, 0 but which is occasionally also found in the bones ofen the forearm and lower leg (Thomas, 1933; Gimlette 1960). The site of bone change thus differs from thato found in osteoarthropathy. Furthermore, radiologically the periostitis of thyroid acropachy is much denser than that seen in pulmonary arthropathy, and resembleso bubbles on the surface of bone. Soft tissue swelling may be present, especially over affected bones, but thew joints are not swollen or tender. The condition is always associated with a past history of hyperthyroidism exophthalmus and pre-tibial myxodema and generally 3 develops after treatment of the hyperthyroidism.

\section{Vascular Anatomy and Function in Hyper-î trophic Pulmonary Osteoarthropathy}

The occurrence of circulatory change in patientse with pulmonary arthropathy was first suggested by응 Bamberger (1891), but the precise nature of anydisturbance of vascular function was not deter- $Z$ mined at that time. Plethysmographic studies of the limb circulation in patients with arthropathy have shown that hand and foot flow were noto raised compared with control subjects, but that mean calf and forearm flow were increased before\% operation and fell after removal of the primagy. pulmonary tumour (Ginsburg, 1958).

The raised level of forearm and calf flow was attributed to increased vascularity in the deepō tissues associated with new bone formation. Confirmation of increased vascularity in bone and $\stackrel{\mathbb{Q}}{\complement}$ surrounding connective tissue was provided by $\vec{O}$ arteriographic and histological studies (Ginsburg, $Э$ 1958; Holling, Brodey and Boland, 196r). Studies in dogs with pulmonary arthropathy have shown further that the earliest anatomical change in the limbs, which preceded the development of $\exists$. periostitis along the shafts, was an overgrowth of highly vascularized connective tissue round the distal parts of the bones and tendons (Holling and others, $196 \mathrm{I}$ ).

The fact that a tense, painful swelling of the shin음 or distal forearm is not infrequently observed in patients with osteoarthropathy may indicate the occurence of similar changes in the human limb, as N illustrated in the post-mortem specimen shown in Fig. 2.

Changes in the vasculature in this condition are probably not confined to the limbs. Studies of the bronchial circulation in patients with clubbing ofo the fingers in some cases complicated by osteo- $\mathbb{\mathbb { D }}$ arthropathy (Cudkowicz and Armstrong, I953; Cudkowicz and Wraith, 1957; Cudkowicz, Abelmann, Levinson, Katznelson and Jreissaty, I960;윰 


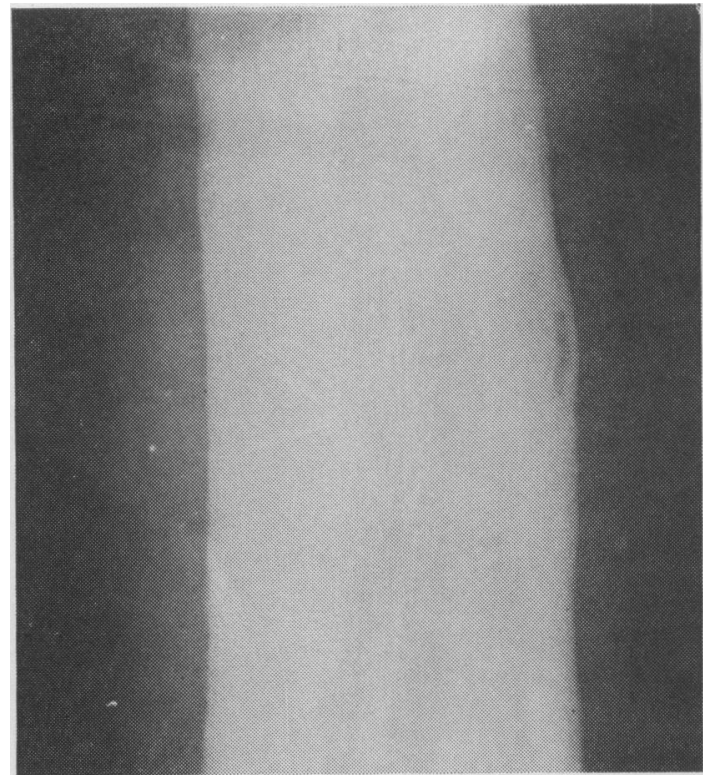

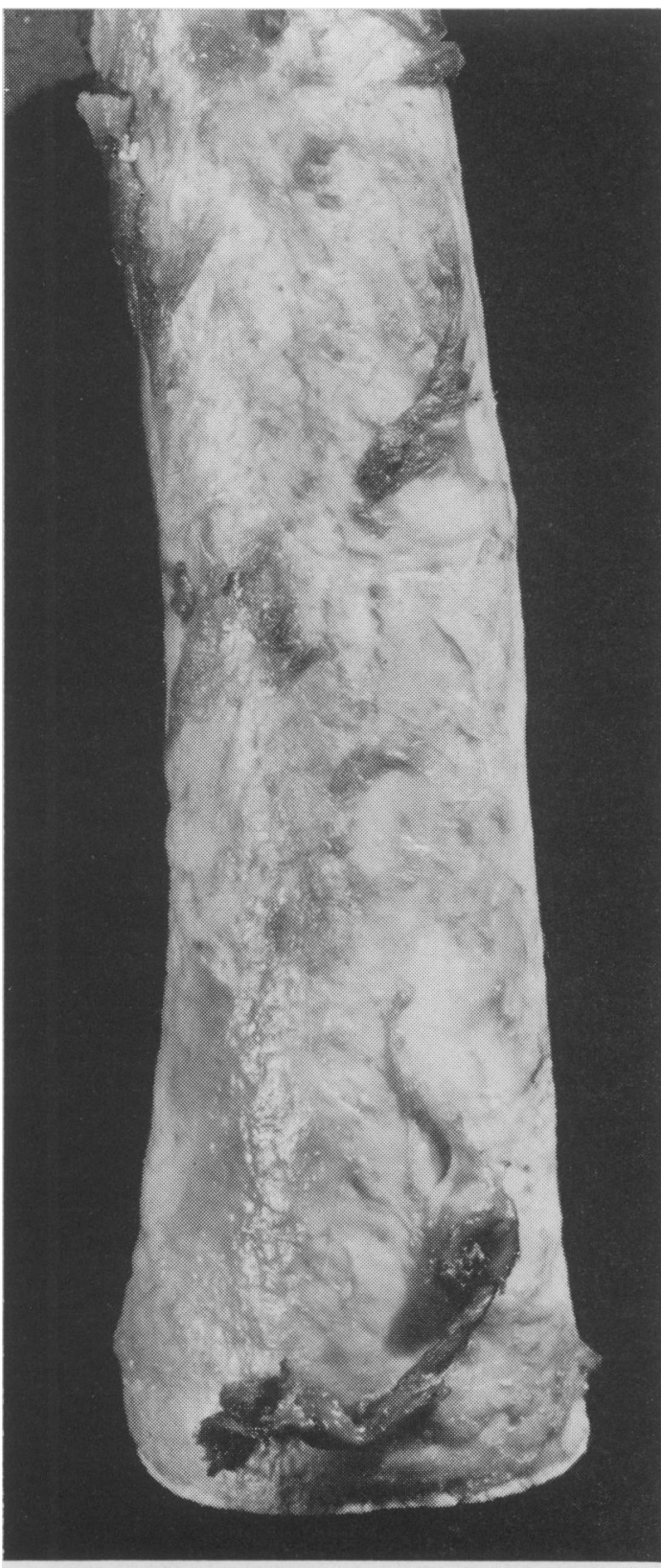

FIG. $2(b)$.

Fig. 2.-Post-mortem specimen of femur from patient with hypertrophic pulmonary osteoarthropathy secondary to carcinoma of the bronchus. (a) X-ray of corresponding part of bone, $(b)$ and $(c)$ surface views of bone showing irregular vascular periosteal proliferation and vascularized connective tissue.

I96I) indicated the presence of increased vascularity in this region as in the lungs and the periphery.
Turner-Warwick, 1961) provided evidence of a considerable increase in bronchial arterial flow in such patients. A preliminary study of the cesophageal arteriolar network in patients with clubbing and osteoarthropathy (Turner-Warwick, 


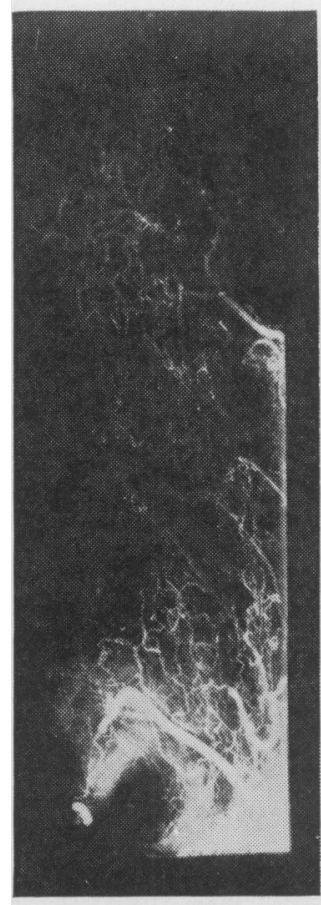

(a)

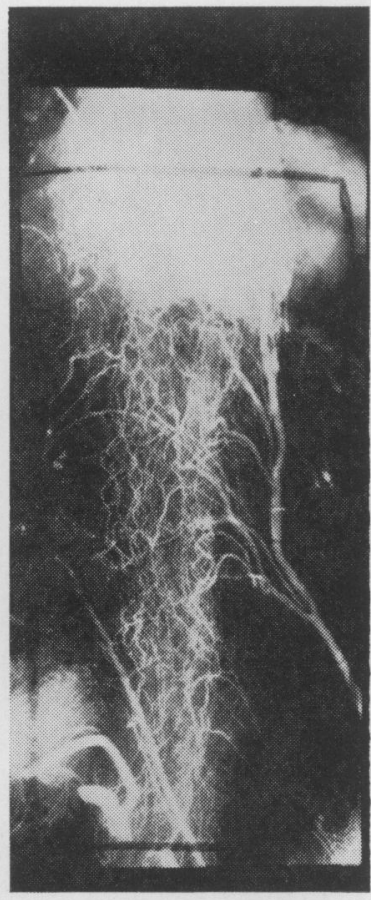

(b)

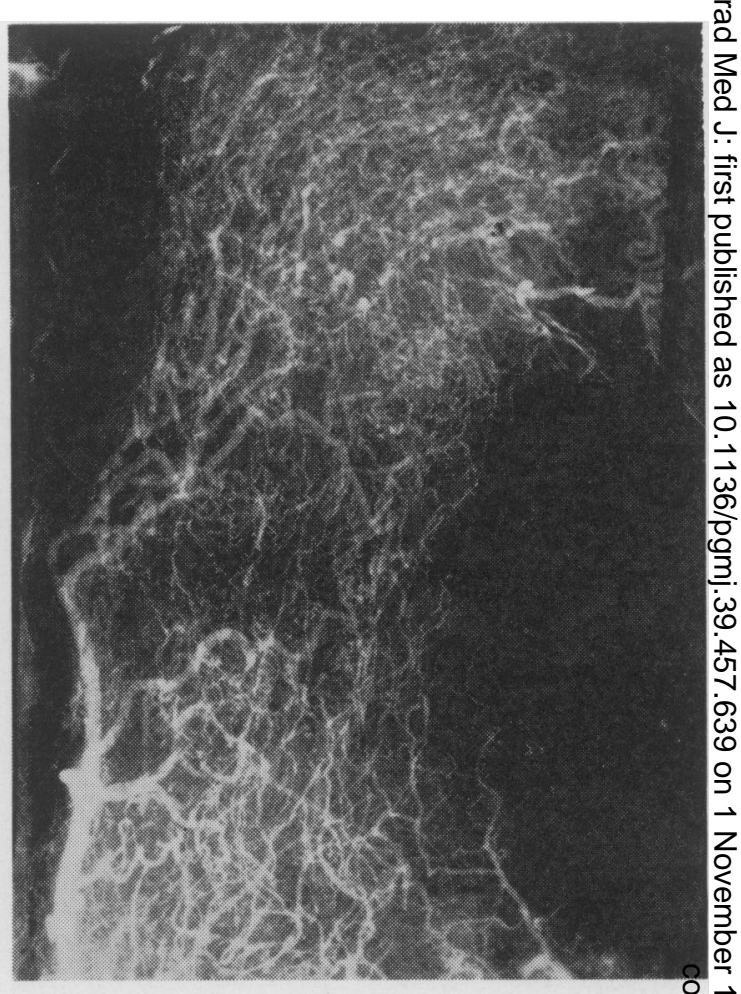

(c)

FIG. 3.-Antero-posterior radiographs of œsophagus showing post-mortem vascular pattern. Micropaque (80\%) a gelatin $(15 \%)$ injected after initial clearing with saline: penetration, 30 microns. (a) Normal x $2.5 ;(b)$ patient wi osteoarthropathy (as in Fig. I) $x$ 2.5; (c) patient with osteoarthropathy (as in Fig. I and Fig. $3(b)$ ) $\times 4$. (By courtesy of Dr. M. E. Turner-Warwick.)

\section{Other Anomalies}

Though lesions in bone and joint are generally the most striking change in pulmonary arthropathy, anomalies may also be found in other systems. Thus, gynæcomastia as an occasional accompaniment of this syndrome was noted by Bamberger ( $189 \mathrm{I}$ ) and by later workers (Fried, I943; Bloom, 1948; Bariety and Coury, 1950). More recently, it was found that, irrespective of the presence of gynæcomastia, mean œstrogen excretion in a group of patients with hypertrophic pulmonary osteoarthropathy was more than twice that recorded in a control group of patients with carcinoma of the bronchus and clubbing of the fingers uncomplicated by arthropathy or in healthy men (Ginsburg and Brown, 196r) and fell to within normal limits some weeks after removal of the primary pulmonary tumour. Though no absolute correlation was demonstrated, œstrogen excretion was greater in subjects with marked periostitis that in those with minimal radiological change. It is therefore of interest that, in liver disease, where clubbing and even osteoarthropathy may occur, urinary cestrogens were also raised in

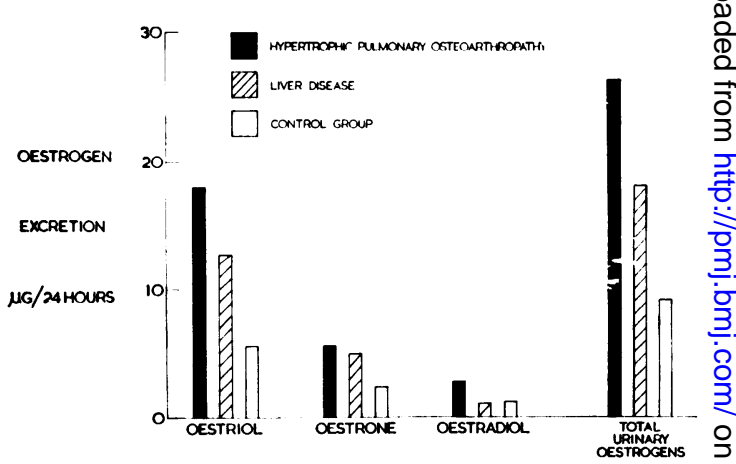

FIG 4.-Estrogen excretion in a group of patients $>$ with hypertrophic pulmonary osteoarthropathy을. (solid histograms) in a group of patients with liver disease (hatched histograms) and in a controlo group (open histograms) data from Ginsburg and Brown (1961) and Crean, Brown and Ginsburg오 ( 1963 ).

some patients compared with normal (Cameron, r957a and b; Crean, Brown and Ginsburg, r963).

The origin of the increased urinary ostrogens? produced in some patients with arthropathy is 0 obscure. Conjugation and inactivation of nstro- 


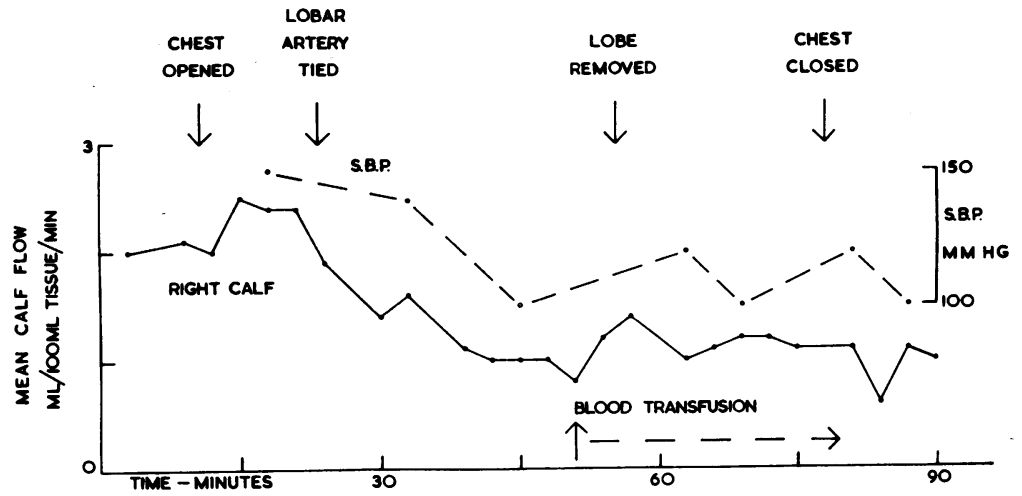

Fig. 5.-Calf blood flow (continuous line) and systolic blood pressure (interrupted line) before and during right middle lobectomy in a patient with hypertrophic pulmonary osteoarthropathy.

gens were not apparently impaired in this condition (Ginsburg and Brown, I96I) and in subsequent studies there was no evidence of altered metabolism of œstrogen precursors such as testosterone (Ginsburg and Brown, unpublished observations). Nor did adrenal suppression by dexamethasone influence œstrogen excretion before removal of the pulmonary tumour in one patient.

\section{Relation Between Clubbing and the develop- ment of Hypertrophic Osteoarthropathy}

An adequate explanation of the mechanism by which pulmonary disease may induce such profound changes in skeletal, vascular and endocrine function is not available. Any discussion of current theories of causation is bedevilled by an unfortunate.confusion of nomenclature, the terms clubbing and osteoarthropathy having been used synonymously and indiscrimately by many workers, the lack of precision in this respect being such as to render many studies valueless. There is undoubtedly some relation between the occurrence of simple finger clubbing limited to fusiform expansion of the terminal phalanx and the development of a characteristic periostitis in the limbs, for periosteal change rarely occurs in subjects in whom clubbing of the fingers does not also coexist, and the most advanced form of clubbing is classically seen in such cases. There are, however, a number of facts which suggest that different mechanisms may be involved in the production of the two phenomena.

(r) Though the basic cause of simple clubbing and of the more complex condition is generally intrathoracic and occasionally hepatic disease, the incidence of osteoarthropathy in different diseases does not parallel the frequency with which finger clubbing occurs in these conditions. Thus, clubbing is a common finding in congenital heart disease, subacute bacterial endocarditis and interstitial pulmonary fibrosis, but osteoarthropahy is extremely rare in such patients; only three cases of arthropathy were seen in a series of over 3,000 patients with cyanotic heart lesions (Trever, 1958).

(2) Clubbing may be due to local causes such as a peripheral arteriovenous aneurysm, and may then be asymmetrical and restricted to one limb or digit. Periosteal involvement, however, is symmetrical, associated only with systemic disease and not with any purely local cause.

(3) Though clubbing is generally well established before the onset of pulmonary arthropathy, a few cases have been reported with definite periostitis and joint involvement prior to the appearance of clubbing (Holling, Brodey and Boland, 1960; Ayre, 1957; Pattison, Beck and Miller, 195 I ; Rasmussen, 1952).

(4) Cortisone or vagotomy may relieve the pain associated with osteoarthropathy, but without influencing the degree of clubbing.

(5) Finally, the occurrence of gynæcomastia and raised urinary œstrogens in patients with pulmonary arthropathy, but not in those with simple clubbing (Ginsburg and Brown, I96r), provides further evidence that the development of osteoarthropathy depends on factors other than those which determine changes in the distal parts of the digits.

The assumption that osteoarthropathy is merely an advanced stage of clubbing, the process having extended to involve bone and the more proximal parts of the limb (Mendlowitz, 1942, 1954) is therefore not justified and one may conclude that the onset of periostitis and other lesions depends on factors additional to those which determine the production of simple clubbing (Ginsburg, 1963).

\section{Theories of Causation}

The development of osteoarthropathy was originally ascribed to the action of a toxic substance absorbed into the circulation from bronchiectatic sputum (Marie, I890; Bamberger, 1890), but injection of sputa (Bamberger, 1890) or tissue extracts (Phemister, 1917; Thiers, Berard, Planchu, and Haour, I95I) from patients with arthropathy into experimental animals failed to reproduce the syndrome. In any case, periostitis may occur in patients with non-suppurative intrathoracic disease.

The frequent occurrence of dyspnœa and cyanosis in patients with pulmonary arthropathy has led to the widespread belief that it is caused by a circulatory disturbance but the site and nature of this change has not been defined. The most widely quoted hypothesis is that periostitis results 
from an increased peripheral blood-flow which is greater than the nutritional needs of the tissues (Mendlowitz, I942; Mendlowitz and Leslie, 1942; Mendlowitz, I954). The peripheral blood-flow may, however, be increased in many conditions, such as thyrotoxicosis, pregnancy and arteriovenous aneurysms of the limbs, but osteoarthropathy is not a feature of such cases. Furthermore, the increased vascularity in limbs with pulmonary arthropathy is most marked in regions of new bone and connective tissue formation, and neither hand blood-flow (Ginsburg, I958), nor maximal heat elimination from the fingertip (Mendlowitz, r94I) were increased in this condition. The new vessel formation should therefore be regarded as an accompaniment of the process and as an essential feature, rather than the primary cause.

The symptomatic effect of vagotomy in some patients with arthropathy has led to the suggestion that osteoarthropathy results from a nervous reflex evoked in the chest (Flavell, 1956; Holling and others, I96I). On the assumption that the peripheral manifestations of the syndrome depended on the activity of afferent impulses arising from nerve endings in the thorax, Holling (Holling and his colleagues 196r ; Holling, Denielson, Hamilton and Blakemore 1963 ) attempted to trace the pathway of such nerve fibres. The effect on osteoarthropathy of interrupting nervous pathways in the chest was assessed solely in terms of the change in blood-flow induced in affected limbs. A reduction in peripheral flow was demonstrated in some cases after section or infiltration of the trunk of the vagus high in the neck. The involvement of afferent fibres from the parietal pleura travelling along the intercostal trunks was also suggested, but the efferent pathway of this reflex has not been determined. That factors other than vagal block may be involved is shown in Fig. 5, a record of the change in calf blood-flow before and duringa lobectomy. Limb blood-flow decreased shortly? after tying of the main artery to the right middleo lobe in a patient with arthropathy and fell pro- $C$ gressively for the next twenty minutes. A similar fall in systolic blood pressure was observed during? this period. Calf blood-flow increased slightly after a blood transfusion was set up, but still remained below the pre-operative level when lobectomy was complete.

Thus, the fact that vagal or intercostal block maye alter limb blood-flow does not solve the mechanismo of production of osteoarthropathy and it is still necessary to define the precise stimulus causing ${ }^{\omega}$ overgrowth of both vascular connective tissue ando bone.

The possibility that humoral factors may bee्ల responsible has not been excluded. The fact thate cross circulation between the limb of a normal dog $N$ and one with arthropathy for only half-an-houri caused no change in blood flow (Holling and otherse 1960, 1961) may merely reflect the time requiredo for the development of tissue change. The presence of increased urinary œstrogens in some patients favours the possibility of metabolic change, but whether increased œstrogen excretion 3 is directly related to the mechanism responsible for periosteal growth, or whether it is merely incidental abnormality, is one of the many factorso requiring further study. The problem at present not the provision of a new theory, but the absenceo of a reliable method for producing the conditions in experimental animals and the paucity of bio-o chemical studies in patients with pulmonaryo osteoarthropathy.

Some of the studies described were supported by grants from the Endowment Fund of St. Thomas'sHospital and from the British Empire Cancer Campaign:

\section{REFERENCES}

ANGel, J. (1957): Pachydermo-periostosis (Idiopathic Osteoarthropathy), Brit. med. F., ii, 789.

AYRE, W. B. (1947): A Case of Hypertrophic Osteoarthropathy, Canad. med. F., 56, 7I.

BAMBERGER, E. vON (1891): Ueber Knochenveränderungen bei Chronischen Lunger- und Herzkrankheiten, $Z$. klin. Med., 18, 193.

BarIETY, M., and Coury, C. (1950): L'ostéo-arthropathie Hypertrophiante Pneumique et les Dysacromélies d'Origine $\bigcirc$ Thoracique: Aspects Anatomo-cliniques et Evolutifs (a propos de 25 cas), Sem. Hop. Paris, 26, r681.

Bloom, W. (1948): Pituitary Implications in Hypertrophic Pulmonary Osteoarthropathy, Ann. intern. Med., 29, 36r. CAmeron, C. B. (1957a): The Liver and Steroid Hormone Metabolism, Brit. med. Bull., 13, I19.

- (1957b): Urinary Excretion of Estrone, Estrachiol-17 and Estriol in Patients with Chronic Liver Damage,, F. Endocr., 15, 199.

CAMP, J. D., and Scanlan, R. L. (1948): Chronic Idiopathic Hypertrophic Osteoarthropathy, Radiology, 50, 581.

COMPËRE, E. L., ADAMS, W. E., and CoMPÈRE, C. L. (1935): Generalized Hypertrophic Pulmonary Osteoarthropathy: Experimental and Clinical Study with a Report of Two Cases, Surg. Gynec. Ostet., 6r, 312.

Coury, C. (1960): 'L'Hippocratisme Digital'. Paris: Bailliere et Fils.

Crean, G. J., Ginsburg, J., and Brown, J. B. (1963): Estrogen Excretion and Metabolism in Liver Disease, Gut? (in the press).

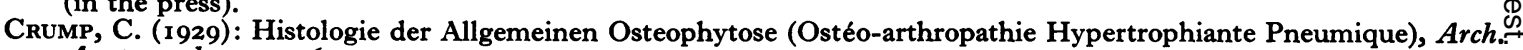

Anat., path., $271,467$.
Cudkowicz, L., and Armstrong, J. B. (1953): Finger Clubbing and Changes in the Bronchial Circulation. Brit. 7.00 Tuberc., 47, 227. 
—, and Wraith, D. G. (1957): A Method of Study of the Pulmonary Circulation in Finger Clubbing, Thorax, 12, 313 .

, Abelmann, W. H., Levinson, G. E., Katznelson, and Jreissaty, R. M. (ig60): Bronchial Arterial Blood Flow, Clin. Sci., r9, $\mathbf{1}$.

Diner, W. C. (I962): Hypertrophic Osteoarthropathy, F. Amer. med. Ass., 181, 555.

FrIed, B. M. (1943): Chronic Pulmonary Osteoarthropathy: Dyspituitarism as a Probable Cause, Arch. intern. Med., $72,565$.

Gall, E. A., Bennett, G. A., and Bauer, W. (1951): Generalized Hypertrophic Osteoarthropathy: A Pathologic Study of Seven Cases, Amer. F. Path., 27, 349 .

Gilbert, T. A., and Fournier, F. (I895): La Cirrhose Hypertrophique avec Ictere chez les Enfants, C.R. Soc. Biol. (Paris), 2, 4I9.

GimmletTe, T. M. D. (1960): Thyroid Acropachy, Lancet, i, 22.

GinsBurg, J. (1958): Observations on the Peripheral Circulation in Hypertrophic Pulmonary Osteoarthropathy, Quart. F. Med., N.S., 27, 335.

(1959): The Effects of Certain Stimuli on the Peripheral Circulation in Healthy and Diseased Subjects (D.M. Thesis, University of Oxford).

, and BRown, J. B. (196I): Increased CEstrogen Excretion in Hypertrophic Pulmonary Osteoarthropathy, Lancet, ii, 1274 .

- (1963): Clubbing of the Fingers (in the press). American Physiological Society. 'Handbook of Physiology'.

Hansen, J. L. (1952): Bronchial Carcinoma Presenting as Arthralgia, Acta med. scand. Suppl., 226, 47.

Holling, H. E., BRodey, R. S., and Boland, H. C. (1960): Pulmonary Osteoarthropathy, Trans. Ass. Amer. Phys., 53, 305 .

53, (1961): Pulmonary Hypertrophic Osteoarthropathy, Lancet, ii, I269.

, Danielson, G. K., Hamilton, R. W., and Blakemore, W. S. (1963): Hypertrophic Pulmonary Osteoarthropathy, F. thorac. Surg. (in the press).

MarIE, P. (1890): De l'Ostéo-arthropathie Hypertrophiante Pneumonique, Rev. Med. (Paris), Io, I.

Mendlowitz, M. (1938): Some Observations on Clubbed Fingers, Clin. Sci., 3, 387.

- (194I): Measurement of Blood Flow and Blood Pressure in Clubbed Fingers, f. clin. Invest., 20, 113.

- (IG42): Clubbing and Hypertrophic Osteoarthropathy, Medicine, 2I, 269.

(1954): 'The Digital Circulation'. New York: Grune and Stratton.

- and LesLie, A. (1942): Experimental Simulation in the Dog of the Cyanosis and Hypertrophic Osteoarthropathy which are Associated with Congenital Heart Disease, Amer. Heart F., 24, I4I.

Meyer, G. D. E., and Sarasin, P. (1950): Un cas d'Ostéoarthropathie Hypertrophiante Pneumique de Pierre Marie associée à une Cirrhose Biliaire, Schweiz. med. Wschr., 80, 1230.

Parkes-Weber, F. (1909): The Histology of the New Bone Formation in a Case of Pulmonary Hypertrophic Osteoarthropathy, Proc. roy. Soc. Med., 2, 187.

Parmentigr, E., and CASTAigne, F. (1905): Ostéo-arthropathie et Cirrhose Hypertrophique Biliaire, Bull. Soc. Med. Hôp. Paris, 18, 275.

Pattison, J. B., Beck, E., and Miller, W. B. (1951): Hypertrophic Osteoarthropathy in Carcinoma of the Lung, 7. Amer. med. Ass., 146, 783.

Phemister, D. B. (1917): Chronic Lung Abscess with Pulmonary Hypertrophic Osteoarthropathy, Surg. Clin. Chicago, I, $38 \mathrm{r}$.

Price Thomas, C., and Drew, C. E. (1953): Fibroma of the Visceral Pleura, Thorax, 8, 180.

RASMUSSEN, H. (1952): Peripheral Vascular Disease, with Hypertrophic Osteoarthropathy, as First Manifestation of Bronchial Carcinoma, Acta med. scand. Suppl., 266, 855.

Ray, E. S., and FisheR, H. P. (1953): Hypertrophic Osteoarthropathy in Pulmonary Malignancies, Ann. intern. Med., 38, 239 .

Semple, T., and McCluskie, R. A. (1955): Generalized Hypertrophic Osteoarthropathy in Association with Bronchial Carcinoma: A Review Based on 24 Cases, Brit. med. F., $1,754$.

Sk̀ze, S. DE, Hubault, T., and Debeyre, N. (1952): Hippocratisme Digital avec Arthropathie, d'Origine Pneumique: Effet du Traitement par la Cortisone, Bull. Soc. Med. Hôp. Paris, 68, 495.

Shapiro, S. (1956): Hypertrophic Osteoarthropathy, Arch. intern. Med., 93, 700.

Thiers, H., Berard, M., Plauchu, L., and Haour, M. (1951): Dystrophies de Nature Diverses chez le Cobaye voie de Croissance Traité par les Extraits d'un Cancer Provocateur chez l'Homme d'une Ostéopathie Hypertrophiante Pneumique de Pierre Marie, Rev. Rhum., 18, 295.

Thiodet, J., Fourrier, A., Chevrot, L., and Massonat, J. (1950): Echinococcose Pulmonaire et Osteo-arthropathie Hypertrophiante Pneumique de Pierre Marie, Bull. Soc. Med. Hôp. Paris, 66, 1769.

Thomas, H. M. (1933): Acropachy: Secondary Subperiostal New Bone Formation, Arch. intern. Med., 5I, 271.

Touraine, A., Solente, G., and Golé, L. (1935): Un Syndrome Ostéodermopathique: La Pachydermie Plicaturée avec Pachyperiostose des Extremités, Presse med., 43, 1820.

Trever, R. W. (1958): Hypertrophic Osteoarthropathy in Association with Congenital Cyanotic Heart Disease: A Report of Two Cases, Ann. intern. Med., 48, 660.

Turner-Warwick, M. E. H. (1961): Bronchial Artery Patterns in Pulmonary and Cardiovascular Disease (Ph.D. Thesis, University of London).

Vogr, A., and Goldfischer, S. (1962): Pachydermoperiostosis, Amer. F. Med., 33, 166.

Wierman, H., Claggett, O. T., and MCDonald, J. R. (1954): Articular Manifestations in Pulmonary Diseases: An Analysis of Their Occurrence in I,024 Cases in which Pulmonary Resection was Performed, f. Amer. Med. Ass., $155,1459$.

Wyburn-Mason, R. (1948): Bronchial Carcinoma Presenting as Polyneuritis, Lancet, i, 203. 